\title{
Decline of coral reefs during late Paleocene to early Eocene global warming
}

\author{
C. Scheibner ${ }^{1}$ and R. P. Speijer ${ }^{2}$ \\ ${ }^{1}$ Universität Bremen, FB5, P.O. Box 330440, 28334 Bremen, Germany \\ ${ }^{2}$ Department of Earth and Environmental Sciences, K.U.Leuven, Celestijnenlaan 200E, 3001 Leuven, Belgium
}

Received: 13 August 2007 - Published in eEarth Discuss.: 25 October 2007

Revised: 15 April 2008 - Accepted: 13 May 2008 - Published: 10 July 2008

\begin{abstract}
Since the 1980s the frequency of warming events has intensified and simultaneously widespread coral bleaching, and enhanced coral mortality have been observed. Yet, it remains unpredictable how tropical coral reef communities will react to prolonged adverse conditions. Possibly, coral reef systems are sufficiently robust to withstand continued environmental pressures. But if coral mortality increases, what will platform communities of the future look like? The co-evolution of early Paleogene carbonate platforms and palaeoclimate may provide insight. Here we document the impact of early Paleogene global warming on shallow-water carbonate platforms in the Tethys. Between 59 and $55 \mathrm{Ma}$, three discrete stages in platform development can be identified Tethys-wide: during the first stage carbonate platforms mainly consisted of coralgal reefs; during the second - transitional - stage coralgal reefs thrived only at middle latitudes and gave way to larger foraminifera as dominant carbonate producer in low latitudes; finally, during the third stage, newly developing larger foraminifera lineages completely took over the role as main carbonate-producing organisms in low to middle latitudes. We postulate that rising temperatures led to a stepwise demise of Paleocene coral reefs, giving way to an unprecedented expansion of larger foraminifera, dominating Tethyan platforms during the early Eocene.
\end{abstract}

\section{Introduction}

Modern reef-building corals are sensitive to slight increases in summer sea-surface temperature (SST) and react by symbiont-loss due to bleaching. Bleaching in corals is a reaction to accelerated stress, primarily related to intensity and

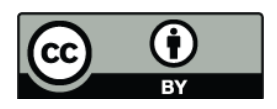

Correspondence to: C. Scheibner (scheibne@uni-bremen.de) duration of elevated temperatures and with high solar irradiance and disease as subsidiary causes (Harvell et al., 2002). While high temperatures affect the living corals, internal and external bioeroders are largely unaffected, and in combination with microbes and viruses, they can contribute to an accelerated decline of coral reefs (Harvell et al., 2002). Investigations on today's reefs and corals reveal that increases in maximum SST's of about $1^{\circ} \mathrm{C}$ above mean summer maximum temperatures are sufficient to cause bleaching (Kleypas et al., 2001; Hughes et al., 2003). However, the bleaching threshold of corals not only depends on an absolute temperature threshold, but also varies regionally (Hughes et al., 2003). In 1998, more than $90 \%$ of shallow-water corals in Indian Ocean reefs were killed in response to anomalously high sea-surface temperatures (SST), but lethal threshold temperatures ranged widely between $29^{\circ}$ and $34^{\circ} \mathrm{C}$. This indicates that temperature anomalies within individual regions are of greater importance than absolute temperatures (Sheppard, 2003). Another group that shows bleaching is the larger foraminifera. But this group and their photosynthetic symbionts appear to be less sensitive to elevated summer temperatures and bleaching is thought to be induced by light intensities (Hallock, 2005). The consequences of the recent warming on corals and coral reefs on a seasonal or yearly scale are widely debated in recent literature, but on geological scale, information is still missing. Obviously, this topic is highly complex and other factors besides temperature contributed to the decline of coral reefs, such as $\mathrm{CO}_{2}$, precipitation, run-off, variation of $\mathrm{Mg} / \mathrm{Ca}$ ratios, evolutionary trends within larger foraminifera and varying trophic resource regimes. Yet, we believe that rising temperature is an overall parameter in environmental change around the Paleocene/Eocene boundary. Therefore, in this paper we concentrate on the temperature effect and document the impact of short-term and long-term global warming on coral reefs at early Paleogene circumTethyan carbonate platforms. 


\section{Bio- and chemostratigraphy}

The stratigraphy of the Paleocene/Eocene boundary interval in shallow-water carbonate settings is relatively well-defined, as biostratigraphy as well as chemostratigraphy can be used for age determinations. Serra-Kiel et al. (1998) provided a shallow benthic zonation (SBZ) and a correlation scheme of platform and pelagic communities for the Paleocene-Eocene Tethys. The Larger Foraminifera Turnover (LFT) is an important event that occurred within the P/E-boundary interval. The LFT is characterized by the start of adult dimorphism and large shell size in larger foraminifera, especially within the nummulitids and alveolinids. For practical reasons, Hottinger (1998) proposed the LFT as a criterion for delineating the P/E boundary in platform deposits, as this boundary can be easily recognized in the field by "hand lens". Recent investigations in the Pyrenees (Orue-Extebarria et al., 2001; Pujalte et al., 2003) and Egypt (Scheibner et al., 2005; Scheibner and Speijer, 2008) show that this pragmatic placement of the P/E boundary in the shallow-water domain happens to correlate with the carbon isotopic excursion (CIE) marking the base of the Eocene. While in several other Paleogene time slices the dating by means of shallow benthic biostratigraphy is less precise than the open marine biostratigraphy, in the $\mathrm{P} / \mathrm{E}$ interval it is vice versa. During this time span open marine biozone NP9 correlates with three shallow benthic biozones (SBZ4-SBZ6). The combination of palaeontological (calcareous nannofossils, planktic foraminifera, smaller and larger benthic foraminifera), geochemical $\left(\delta^{13} \mathrm{C}\right)$ and sedimentological data therefore not only allows a precise correlation of the Paleocene and lowest Eocene deep- and shallow-water sections but also an accurate relative dating of the events in shallow-water deposits.

\section{Material and methods}

Here we address the decline of coral reefs during the early Paleogene through intensive thin-section analyses of more than 1000 samples from a low palaeolatitude setting (Galala Mountains, Egypt) and a middle palaeolatitude setting (Pyrenees, Spain and France). This field-based study, particularly concentrating on the Egyptian sections, is complemented by a thorough literature review of Tethyan carbonate platforms from the late Paleocene - early Eocene time interval.

The Galala Mountains are located in the Eastern Desert of Egypt, on the western side of the Gulf of Suez, $200 \mathrm{~km}$ southeast of Cairo. During Maastrichtian to Eocene times, a carbonate platform prograded on top of a structural uplift. For this study eighteen sections were sampled in detail along a platform-basin transect, with a special focus on the late Paleocene to early Eocene. All together about 800 limestone and marl samples were analysed. The limestone samples served for microfacies analysis and were used to establish the biostratigraphy of the shallow-water platform sediments (Scheibner et al., 2003; Scheibner and Speijer, 2008). The marl samples were used for independent age determinations by calcareous nannofossils (NP-zonation) and planktic foraminifera (P-zonation) and for palaeoenvironmental studies. The lower-slope to toe-of-slope sections are of special importance for biostratigraphic correlation of shallow-water and deep-water environments as biostratigraphic marker species from both environments are present in these sections (Scheibner et al., 2005; Scheibner and Speijer, 2008). For several individual sections both types of samples were used for geochemical analyses $\left(\delta^{13} \mathrm{C}\right)$ to trace the CIE in shallow-water and deep-water environments (Scheibner et al., 2005; Scheibner and Speijer, 2008).

During the early Paleogene, the middle palaeolatitude setting in the Pyrenees comprised an elongated east-west trending gulf, which opened westward into the present Bay of Biscay. In this study we integrate data from an earlier microfacies study on Paleogene platform development in the Pyrenees on the basis of more than 400 predominantly limestone samples (Scheibner et al., 2007). Two shallow-water sections are considered, the Campo section, which is the parastratotype section of the Ilerdian and Cuisian and the Serraduy section, both located in Spain.

\section{Early Paleogene decline of coral reefs}

Modern coral reefs can have lateral extensions of up to 2000 km (e.g. Great Barrier Reef). In the Paleogene reef dimensions were much smaller. One of the patch reefs in the Galala Mountains (Egypt) has a height of about $12 \mathrm{~m}$ and a width of about $50 \mathrm{~m}$ (Fig. 1). Few studies provide dimensions, an exception being a subsurface study in Libya, with reef dimensions up to $20 \mathrm{~km}^{2}$ (Terry and Williams, 1969). Tiny reef-like structures of about a metre across are known from the Western Desert, Egypt (Schroeder, 1986). Probably reef dimensions of other Paleogene reefs are of similar order. In general, the composition of late Paleocene reefs varies from region to region between a coral dominated end member (Schroeder, 1986) and an end member dominated by calcareous algae (Baceta et al., 2005).

To date, the history of corals and coral reefs during the early Paleogene is poorly documented, despite a wealth of data on shallow-water carbonate platforms scattered in the literature. Particularly the lower Eocene is well known for its dominance of larger foraminifera on Tethyan shallow-water carbonate platforms (Hottinger, 1998). Various lineages including the genera Nummulites and Alveolina increased in size and diversity in the early Eocene (Hottinger, 1998). Additionally, encrusting foraminifera (Solenomeris/Acervulina) even began to build reef structures (Plaziat and Perrin, 1992). Because of the dominance of larger foraminifera and the relative scarcity of outcropping shallow-water deposits, the evolution of Paleocene coral reefs has generally been overlooked. During the last years we investigated in great 


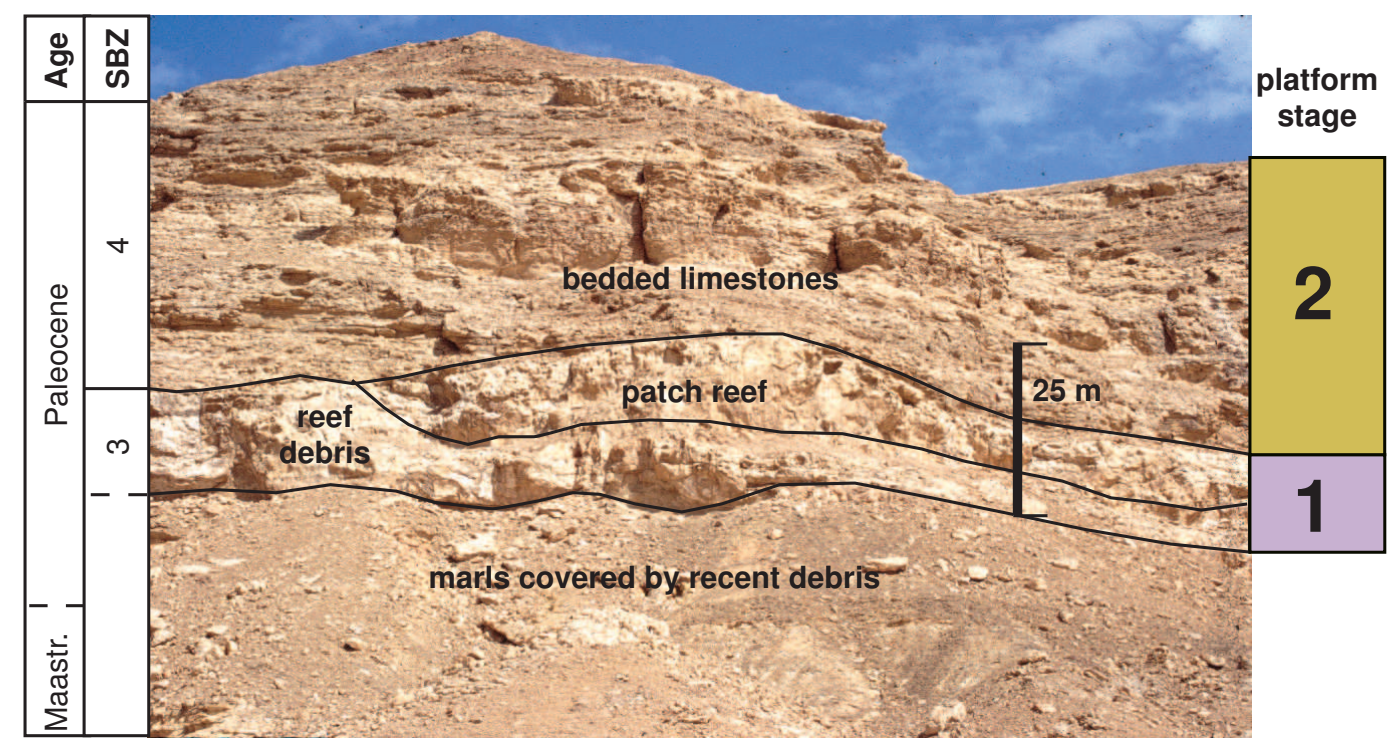

Fig. 1. An isolated patch reef sitting on top of reef-debris (South Galala Mountains/Egypt/section K3 of Scheibner et al., 2003). Below the reef-debris Maastrichtian to Paleocene marls, mainly covered by recent debris, crop out. Bedded limestones of the upper slope cover the patch reef.

detail the platform and biological evolution in two of the best Tethyan exposures of carbonate platform to basin successions of late Paleocene to early Eocene time, i.e. the Galala Mountains in Egypt and the Pyrenees in Spain and France. Especially the combined work on lithostratigraphy, palaeogeography platform evolution (Scheibner et al., 2003, 2005), nannoplankton biostratigraphy (Scheibner and Speijer, 2008), larger foraminifera biostratigraphy and correlation of shallow-water and deep-water biostratigraphies (Scheibner et al., 2005; Scheibner and Speijer, 2008) during the late Paleocene to early Eocene in the Galala Mountains served as the basis for our results. This combined work resulted into a hypothesis about Paleogene platform evolution (Scheibner et al., 2005) that required testing elsewhere. Platform strata of the Pyrenees proved to be ideal testing ground (Scheibner et al., 2007) and this field-based study is combined with a thorough literature review, dealing with other Tethyan late Paleocene to early Eocene carbonate platforms. Altogether 17 early Paleogene Tethyan carbonate platform settings (palaeolatitudes between $43^{\circ} \mathrm{N}$ and $5^{\circ} \mathrm{S}$ ) were established (see supplemental material: http://www.electronic-earth.net/ 3/19/2008/ee-3-19-2008-supplement.pdf). Our data in combination with the literature review reveals that coralgal reefs were common in low to middle latitudes in the Paleocene but had nearly disappeared from the Tethys by the beginning of the Eocene. In the context of this study we define low latitudes as being $0^{\circ}-20^{\circ}$ and middle latitudes as being $>30^{\circ} \mathrm{N}$. The intermediate latitudes between $20^{\circ}-30^{\circ}$ are presented in only two studies (Figs. 2 and 3). In 16 out of 17 study areas three platform stages could be distinguished in full or in part. The first platform stage (shal- low benthic zone 3, SBZ3; 58.9 Ma-56.2 Ma; Figs. 2 and 3 ) is characterized by coralgal reef associations of various coral types and red algae at low to middle palaeolatitudes. Platform stage II (SBZ4; 56.2 Ma-55.5 Ma) is a transitional platform stage, showing a distinct palaeolatitudinal trend. In middle latitudes coralgal reefs continued to flourish, whereas in low latitudes coralgal reefs were replaced by accumulations of larger foraminifera of a first association (Miscellanea, Ranikothalia, Assilina). Solitary corals occurred in platform stage II, but these hardly contributed to the overall sediment budget. The transition of platform stage II to III coincides with the PETM at the Paleocene/Eocene boundary. Platform stage III (SBZ5-6; 55.5 Ma-55? Ma) is characterized Tethys-wide by accumulations of larger foraminifera of a second association (Alveolina, Nummulites, Orbitolites) or encrusting foraminifera (Solenomeris/Acervulina), the latter occasionally building kilometer-sized reefs (Plaziat and Perrin, 1992). Coralgal buildups are absent within platform stage III, except for the Pyrenees (Fig. 2). Especially the species of the second larger foraminifera association are recognized worldwide as dominant carbonate producers. Only the platform in Morocco $\left(23^{\circ} \mathrm{N}\right.$ palaeolatitude) shows a deviating pattern in which oyster reefs and mounds of bryozoans and red algae dominate throughout, fully lacking corals and larger foraminifera. This exceptional situation is explained by the influence of cool and nutrient-rich waters welling up from the Atlantic Ocean (Herbig, 1986). 


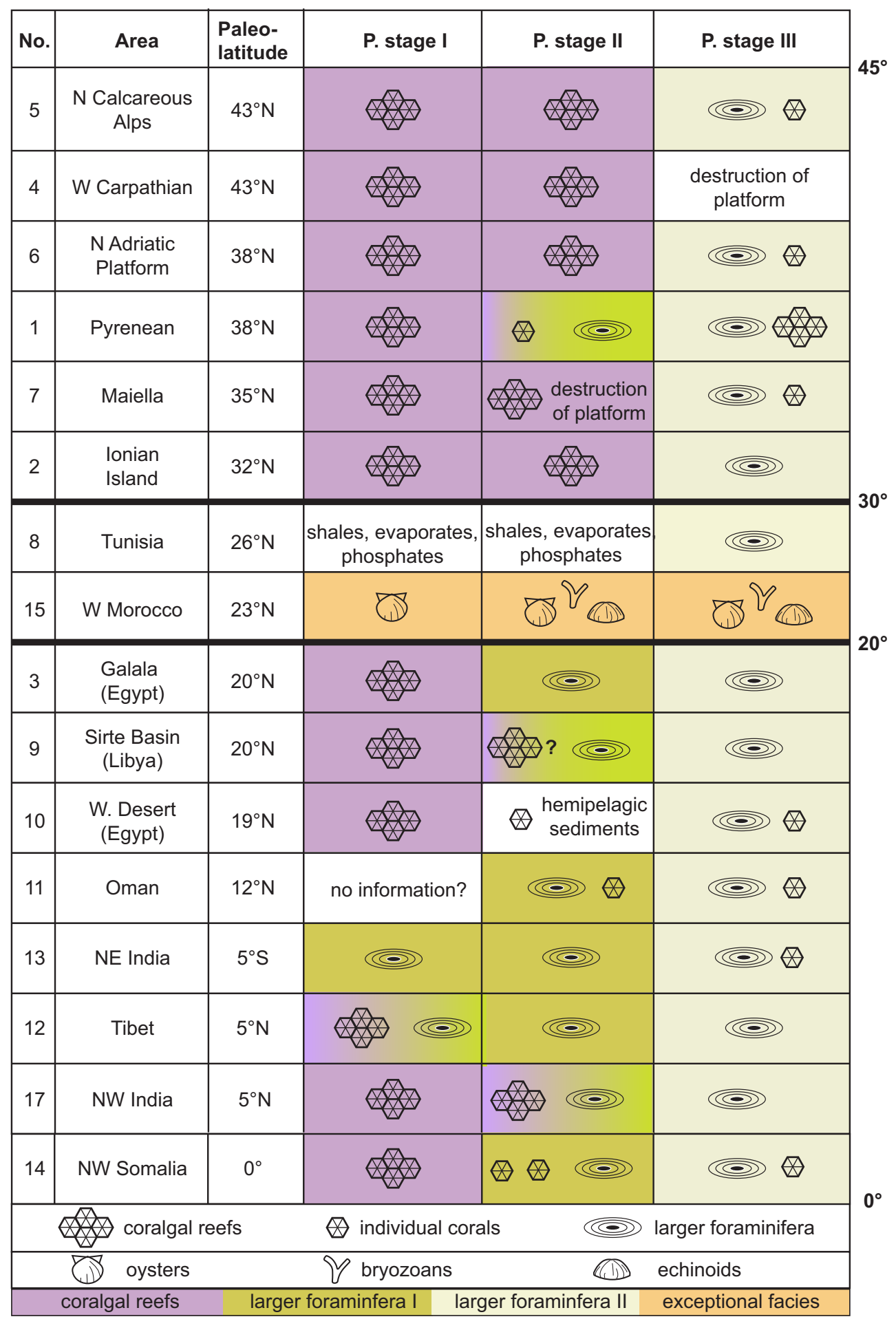

Fig. 2. Overview of carbonate platforms in the Tethyan realm. Platform stage I is clearly dominated by coralgal reefs, whereas platform stage III is clearly dominated by the second larger foraminifera assemblage (Nummulites, Alveolina). The second platform stage is transitional and at middle latitudes characterized by coralgal reefs, whereas the low latitudes are characterized by the first larger foraminifera assemblage (Miscellanea, Ranikothalia, Assilina). The PETM and Paleocene/Eocene boundary are situated between stage II and stage III. References for the localities are given in the supplemental material (http://www.electronic-earth.net/3/19/2008/ee-3-19-2008-supplement.pdf). 


\section{Early Paleogene temperature gradient}

Considering the temperature sensitivity of corals, the early Paleogene evolutionary pattern of tropical platforms demands evaluation in a palaeoclimatic context. The early Paleogene period was characterized by warm, generally icefree conditions (Zachos et al., 2001). These warm conditions culminated during the Early Eocene Climatic Optimum (EECO) at 53-50 Ma (Zachos et al., 2001). The overall warming trend in the early Paleogene was interrupted only between $61 \mathrm{Ma}$ to $58 \mathrm{Ma}$, when a low-amplitude cooling occurred (Zachos et al., 2001) (Fig. 4). On the basis of exceptionally well-preserved planktic foraminifera from Tanzania, Pearson et al. (2007) recalculated late Cretaceous and Eocene tropical SST to be at least $28^{\circ}-32^{\circ} \mathrm{C}$ in contrast to earlier estimates of $20^{\circ}-26^{\circ} \mathrm{C}$ for the Eocene (Zachos et al., 2001) (by comparison, modern tropical SST range between $25^{\circ}-27^{\circ} \mathrm{C}$ (Kump, 2001), Fig. 4). The new data from Tanzania are also thought to indicate a warming trend in tropical regions during the Paleocene and earliest Eocene (Pearson et al., 2007). $\mathrm{Mg} / \mathrm{Ca}$-based temperatures for the late Paleocene have been calculated at $31^{\circ} \mathrm{C}$, while the early Eocene shows the highest temperatures of about $33^{\circ}-34^{\circ}$ (Tripati et al., 2003). For the even warmer period of the PETM a transient rise in sea-surface temperature of $4^{\circ}-5^{\circ} \mathrm{C}$ in low latitudes and $8^{\circ}$ to $10^{\circ}$ in high latitudes is indicated by $\mathrm{Mg} / \mathrm{Ca}$ ratios of planktic foraminifera (Zachos et al., 2003; Tripati and Elderfield, 2004). Furthermore, also in a coastal marine setting at the New Jersey continental margin, USA, (middle palaeolatitude of $35-37^{\circ} \mathrm{N}$ ), Zachos et al. (2006) documented from $\mathrm{TEX}_{86}$ and isotope data a minimum warming of $8^{\circ} \mathrm{C}$ during the PETM, with peak temperatures of $33^{\circ} \mathrm{C}$. Other proxies like molluscan $\delta^{18} \mathrm{O}$ values also point to higher temperatures than previously established by $\delta^{18} \mathrm{O}$-studies of planktic foraminifera (Kobashi et al., 2001). Irrespective of the exact absolute early Paleogene tropical SST, it is unchallenged that the late Paleocene world was warming, that this continued into the early Eocene and that this trend was briefly amplified during the PETM. Ideally, to boost our interpretation, temperature proxy data from the Tethys would be required. Unfortunately reliable SST data from the early Paleogene Tethyan margin are not available, because of usually severe diagenetic overprinting of foraminifera shells retrieved from exposures on land (Charisi and Schmitz, 1998; Zachos et al., 2006). Indirect evidence from the Tethyan realm, however, may be obtained from clay mineralogical changes, suggesting a late Paleocene - early Eocene episode of enhanced warmth and humidity (Bolle and Adatte, 2001), which is in line with the global trend. In the low-latitude Tethys, coeval temperatures must have been even higher.

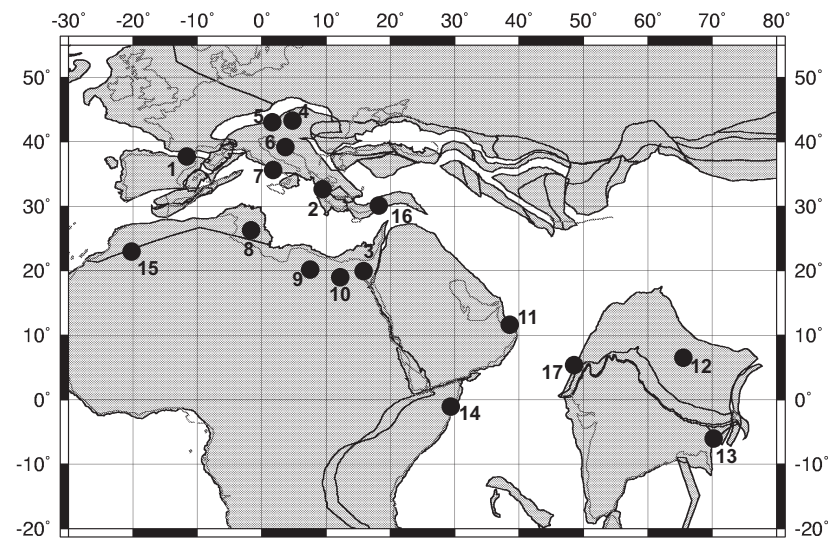

Fig. 3. Localities of studied early Paleogene carbonate platforms. The plate tectonic reconstruction of the Tethys (55 Ma) is constructed from data files used in (http://www.odsn.de/odsn/services/ paleomap/about_map.html) (Hay et al., 1999). Numbers indicate carbonate platforms analyzed for this study. References for the localities are given in the supplemental material (http://www. electronic-earth.net/3/19/2008/ee-3-19-2008-supplement.pdf).

\section{Capacity of coral reefs to withstand the warming}

It is unquestionable that corals/coral reefs suffer from rising sea-surface temperatures if individual/regional threshold values are exceeded. But will coral communities just die or are there any mechanisms to adapt to such a warming? And if so, what is the rate of adaptation? In this paper we cannot solve these questions but instead we present the sequence of events in the early Paleogene that highlight the interaction of warming and coral reef decline. In the case of the short-term PETM (the transition from platform stage II to platform stage III), rising sea-surface temperatures of about $5^{\circ} \mathrm{C}$ in low latitudes and up to $8^{\circ} \mathrm{C}$ in middle to high latitudes (Zachos et al., 2003; Tripati and Elderfield, 2004; Zachos et al., 2006) were probably beyond the range of adaptation capacity for the coral reefs. After the short-term warming of the PETM, the long-term warming trend towards the Early Eocene Climatic Optimum still continued, so that favorable climatic conditions for coralgal reefs were only established after the latter. Typical framework reefs dominated by coral assemblages, nearly absent in the early Paleogene, became the most common type of bioconstruction from middle Eocene times onwards (Geel, 2000; Perrin, 2002), whereas real barrier reefs appeared during the Oligocene (Geel, 2000).

Much more difficult to explain is the transition from platform stage I to platform stage II, as no extreme warming event correlates with this transition. Corals or coral reefs might have been capable to adapt to gradually rising SST. However, in a study on the evolution of different Cretaceous Guyots, located in the Pacific, Jenkyns and Wilson (1999) concluded that these carbonate platforms were drowned during the passage across the equator. High palaeotemperatures 


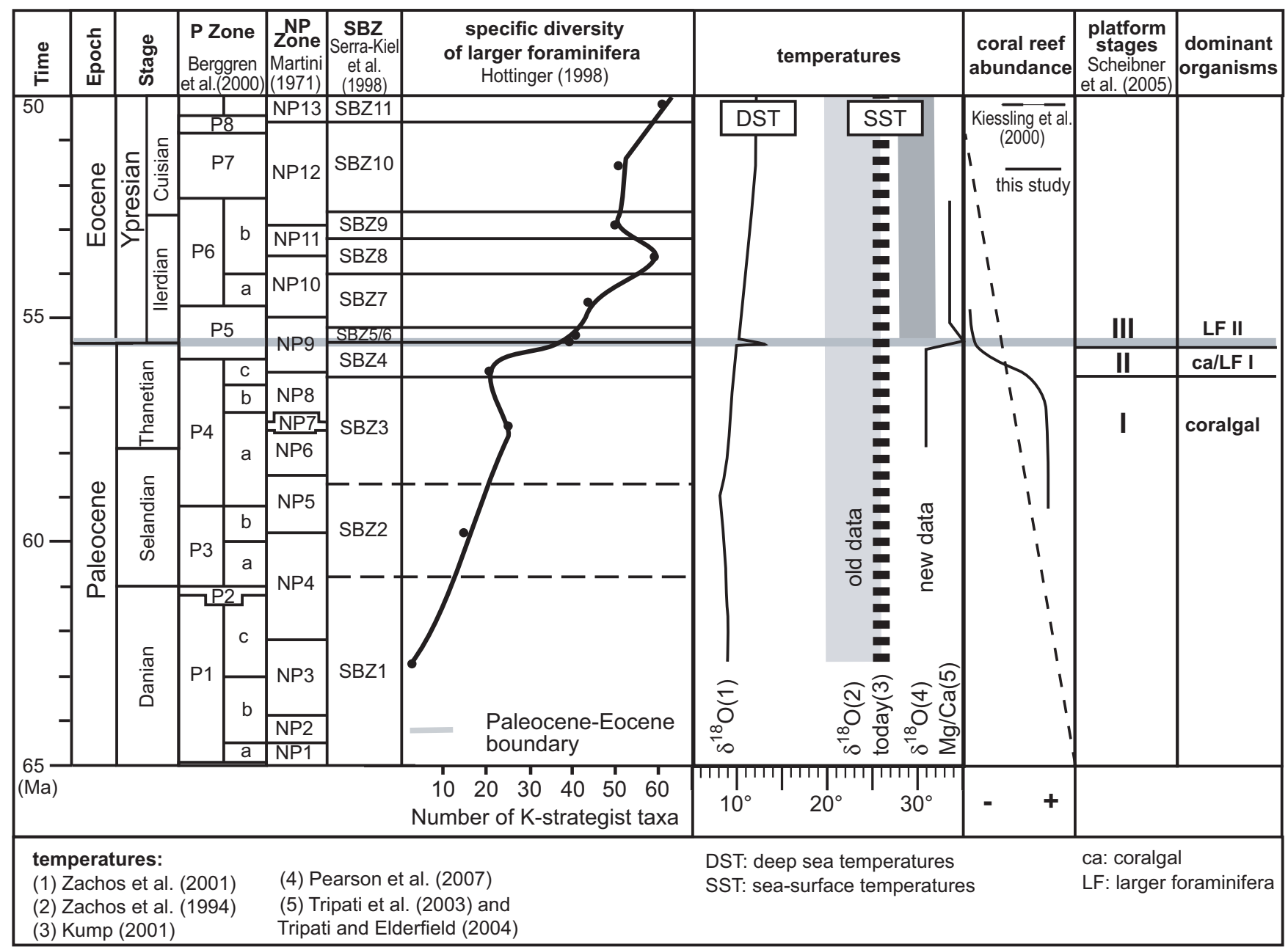

Fig. 4. Biostratigraphy and comparison of trends in evolution and distribution of larger foraminifera, absolute temperatures, coral reef abundances, platform stages and dominant organisms across the Paleocene/Eocene boundary. The grey line marks the Paleocene/Eocene boundary. The shallow benthic zonation described by Serra-Kiel et al. (1998) is slightly modified in line with Scheibner et al. (2005) correlating the Paleocene/Eocene boundary with the base of SBZ5. The study of Kiessling et al. (2000) documents general reef sites and not especially coral reef sites. LFI: larger foraminifera association 1 (Miscellanea, Ranikothalia, Assilina); LFII: larger foraminifera association 2 (Nummulites, Alveolina, Orbitolites).

were adopted as the most reasonable cause for decline and subsequent drowning. The farther away from the equator the platform drowned, the higher the palaeotemperatures had been estimated for this time interval (Jenkyns and Wilson, 1999). During the passage across the equator region the previous shallow-water platforms were exposed to gradually increasing temperatures, which hampered platform growth and subsequently these platforms subsided to water depths, at which a recovery of the platform organisms was impossible. Therefore it might be possible that the Paleogene shift of coralgal reefs from low latitudes to middle latitudes in platform stage II resulted from a similar gradual temperature rise.

Rising temperatures in the early Paleogene were probably one of the main causes, if not the main cause for the decline of the coralgal reefs during that time period. Other factors probably assisted in the initiation of the coralgal reefs decline and hampered a subsequent rise of coralgal reefs after the PETM.

\section{Perspective}

If the warming trend of recent years is going to persist or even intensifies in the decades to come, extant coral reefs are likely to suffer severely (Hallock, 2005) and it would be logical to assume that areas in higher latitudes would become more favorable for reef growth. Such a pole-ward expansion of coral reefs has been observed e.g. in the Holocene in Japan, but present-day estimates suggest that the positive effects of SST rise on geographic expansion of coral 
reefs are very minor in comparison to the overall negative effects (Kleypas et al., 2001). In that case, the early Paleogene scenario can provide a long-term perspective of the changes in organism distributions and carbonate producers that are likely to occur in tropical and subtropical carbonate platforms.

\section{Conclusions}

We postulate that late Paleocene to early Eocene global warming and the superimposed PETM led to the stepwise decline of Tethyan coral reefs. We believe that the direct consequences of temperature rise played a key role in this decline, but other factors associated with global warming also contributed. At $\sim 59-56 \mathrm{Ma}$, just after a cooler period of the middle Paleocene, conditions were favorable for coral reef growth on all margins bordering the Tethys (Stage I). Subsequently, coral reefs first disappeared from the warming tropical to sub-tropical fringes of the southern Tethys, retreating to the cooler northern margin (Stage II). Finally, in response to continued warming and the transient warming during the PETM, coral reefs also vanished from the northern fringes of the Tethys. At the same time, larger foraminifera were increasingly favored as dominant carbonate producing organisms in oligotrophic environments (Scheibner et al., 2005) and were able to fully exploit their niche as judged by their increase in size, rising species diversity and their overwhelming abundance.

Acknowledgements. We thank T. Felis, P. Hallock, J. Hohenegger, P. A. Wilson, W. Kiessling, W. Buddemeier and two anonymous reviewers for critical reading of previous versions of the manuscript.

Edited by: S. Spezzaferri

\section{References}

Baceta, J. I., Pujalte, V., and Bernaola, G.: Paleocene coralgal reefs of the western Pyrenean basin, northern Spain: New evidence supporting an earliest Paleogene recovery of reefal systems, Palaegeography, Palaeoclimatology, Palaeoecology, 224, 117-143, 2005.

Berggren, W. A., Aubry, M. P., van Fossen, M., Kent, D. V., Norris, R. D., and Quillévéré, F.: Integrated Paleocene calcareous plankton magnetobiochronology and stable isotope stratigraphy: DSDP Site 384 (NW Atlantic Ocean), Palaeogeography, Palaeoclimatology, Palaeoecology, 159, 1-51, 2000.

Bolle, M. P. and Adatte, T.: Palaeocene-early Eocene climatic evolution in the Tethyan realm: clay mineral evidence, Clay Minerals, 36, 249-261, 2001.

Charisi, S. D. and Schmitz, B.: Paleocene to early Eocene paleoceanography of the Middle East; the $\delta^{13} \mathrm{C}$ and $\delta^{18} \mathrm{O}$ isotopes from foraminiferal calcite, Paleoceanography, 13, 106118, 1998.

Geel, T.: Recognition of stratigraphic sequences in carbonate platform and slope deposits: Empirical models based on micro- facies analysis of Palaeogene deposits in southeastern Spain, Palaeogeography, Palaeoclimatology, Palaeoecology, 155, 211238, 2000.

Hallock, P.: Global change and modern coral reefs: new opportunities to understand shallow-water carbonate depositional processes, Sedimentary Geology, 175, 19-33, 2005.

Harvell, C. D., Mitchell, C. E., Ward, J. R., Altizer, S., Dobson, A. P., Ostfeld, R. S., and Samuel, M. D.: Climate warming and disease risks for terrestrial and marine biota, Science, 296, 21582162, 2002.

Hay, W. W., DeConto, R., Wold, C. N., Wilson, K. M., Voigt, S., Schulz, M., Wold-Rossby, A., Dullo, W. C., Ronov, A. b., Balukhovsky, A. N., and Soeding, E.: Alternative global Cretaceous paleogeography, in: The evolution of Cretaceous ocean/climate systems, edited by: Barrera, E. and Johnson, C., 1-47, 1999.

Herbig, H. G.: Lithostratigraphisch-fazielle Untersuchungen im marinen Alttertiär südlich des zentralen Hohen Atlas (Marokko), Berliner geowiss. Abh. (A), 66, 343-380, 1986.

Hottinger, L.: Shallow benthic foraminifera at the PaleoceneEocene boundary, Strata, Serie 1, 9, 61-64, 1998.

Hughes, T. P., Baird, A. H., Bellwood, D. R., Card, M., Connolly, S. R., Folke, C., Grosberg, R., Hoegh-Guldberg, O., Jackson, J. B. C., Kleypas, J., Lough, J. M., Marshall, P., Nyström, M., Palumbi, S. R., Pandolfi, J. M., Rosen, B., and Roughgarden, J.: Climate change, human impacts, and the resilience of coral reefs, Science, 301, 929-933, 2003.

Jenkyns, H. C. and Wilson, P. A.: Stratigraphy, paleoceanography, and evolution of Cretaceous Pacific guyots: relics from a greenhouse earth, American Journal of Science, 299, 341-392, 1999.

Kiessling, W., Flügel, E., and Golonka, J.: Fluctuations in the carbonate production of Phanerozoic reefs, in: Carbonate platform systems: components and interactions, edited by: Insalaco, E., Skelton, P. W., and Palmer, T. J., 191-215, 2000.

Kleypas, J. A., Buddemeier, R. W., and Gattuso, J. P.: The future of coral reefs in an age of global change, International Journal of Earth Sciences, 90, 426-437, 2001.

Kobashi, T., Grossman, E. L., Yancey, T. E., and Dockery III, D. T.: Reevalution of conflicting Eocene tropical temperature estimates: Molluskan oxygen isotope evidence for warm low latitudes, Geology, 29, 983-986, 2001.

Kump, L. R.: Chill taken out of the tropics, Nature, 413, 470-471, 2001.

Martini, E.: Standard Tertiary and Quaternary calcareous nannoplankton zonation, in: Proceedings of the II Plankton Conference, edited by: Farinacci, A., Roma, 739-785, 1971.

Orue-Etxebarria, X., Pujalte, V., Bernaola, G., Apellaniz, E., Baceta, J. I., Payros, A., Nunez-Betelu, K., Serra-Kiel, J., and Tosquella, J.: Did the Late Paleocene thermal maximum affect the evolution of larger foraminifers? Evidence from calcareous plankton of the Campo Section (Pyrenees, Spain), Marine Micropaleontology, 41, 45-71, 2001.

Pearson, P. N., van Dongen, B. E., Nicholas, C. J., Pancost, R. D., Schouten, S., Singano, J. M., and Wade, B. S.: Stable warm tropical climate through the Eocene Epoch, Geology, 35, 211-214, 2007.

Perrin, C.: Tertiary: The emergence of modern reef ecosystems, in: Phanerozoic reef patterns, edited by Kiessling, W., Flügel, E. and Golonka, J., 587-621, 2002. 
Plaziat, J. C. and Perrin, C.: Multikilometer-sized reefs built by foraminifera (Solenomeris) from the early Eocene of the Pyrenean domain (S. France, N. Spain): Palaeoecologic relations with coral reefs, Palaeogeography, Palaeoclimatology, Palaeoecology, 96, 195-231, 1992.

Pujalte, V., Orue-Etxebarria, X., Schmitz, B., Tosquella, J., Baceta, J. I., Payros, A., Bernaola, G., Caballero, F., and Apellaniz, E.: Basal Ilerdian (earliest Eocene) turnover of larger foraminifera: Age constraints based on calcareous plankton and $\delta^{13} \mathrm{C}$ isotopic profiles from new southern Pyrenean sections (Spain), in: Causes and consequences of globally warm climates in the early Paleogene, edited by: Wing, S. L., Gingerich, P. D., Schmitz, B., and Thomas, E., 205-221, 2003.

Scheibner, C. and Speijer, R. P.: Recalibration of the Tethyan shallow-benthic zonation across the Paleocene-Eocene boundary; the Egyptian record, Geologica Acta, in press, 2008.

Scheibner, C., Reijmer, J. J. G., Marzouk, A. M., Speijer, R. P., and Kuss, J.: From platform to basin: The evolution of a Paleocene carbonate margin (Eastern Desert, Egypt), Int. J. Earth Sci., 92, 624-640, 2003.

Scheibner, C., Speijer, R. P., and Marzouk, A.: Larger foraminiferal turnover during the Paleocene/Eocene thermal maximum and paleoclimatic control on the evolution of platform ecosystems, Geology, 33, 493-496, 2005.

Scheibner, C., Rasser, M. W., and Mutti, M.: Facies changes across the Paleocene-Eocene boundary: The Campo section (Pyrenees, Spain) revisited, Palaegeography, Palaeoclimatology, Palaeoecology, 248, 145-168, 2007.

Schroeder, J. H.: Diagenetic diversity in Paleocene coral knobs from the Bir Abu El-Husein Area, S Egypt, in: Reef diagenesis, edited by Schroeder, J. H. and Purser, B. H., 133-158, 1986.

Serra-Kiel, J., Hottinger, L., Caus, E., Drobne, K., Ferrandez, C., Jauhri, A. K., Less, G., Pavlovec, R., Pignatti, J., Samso, J. M., Schaub, H., Sirel, E., Strougo, A., Tambareau, Y., Tosquella, J., and Zakrevskaya, E.: Larger foraminiferal biostratigraphy of the Tethyan Paleocene and Eocene, Bulletin de la Société Géologique de France, 169, 281-299, 1998.
Sheppard, C. R. C.: Predicted recurrences of mass coral mortality in the Indian Ocean, Nature, 425, 294-297, 2003.

Terry, C. E. and Williams, J. J.: The Idris "A" bioherm and oilfield, Sirte Basin, Libya - its commercial development, regional Palaeocene geologic setting and stratigraphy, in: The exploration for petroleoum in Europe and north Africa, edited by: Hepple, P., 31-48, 1969.

Tripati, A. K., Delaney, M. L., Zachos, J. C., Anderson, L. D., Kelly, D. C., and Elderfield, H.: Tropical seasurface temperature reconstruction for the early Paleogene using $\mathrm{Mg} / \mathrm{Ca}$ ratios of planktonic foraminifera, Paleoceanography, 18, doi:10.1029/2003PA000937, 2003.

Tripati, A. and Elderfield, H.: Abrupt hydrographic changes in the equatorial Pacific and subtropical Atlantic from foraminiferal $\mathrm{Mg} / \mathrm{Ca}$ indicate greenhouse origin for the thermal maximum at the Paleocene-Eocene boundary, Geochem. Geophys. Geosys., 5, Q02006, doi:10.1029/2003GC000631, 2004.

Zachos, J., Pagani, M., Sloan, L., Thomas, E., and Billups, K.: Trends, rhythms, and aberrations in global climate $65 \mathrm{Ma}$ to present, Science, 292, 686-693, 2001.

Zachos, J. C., Wara, M. W., Bohaty, S., Delaney, M. L., Petrizzo, M. R., Brill, A., Bralower, T. J., and Premoli Silva, I.: A transient rise in tropical sea surface temperature during the PaleoceneEocene Thermal Maximum, Science, 302, 1551-1554, 2003.

Zachos, J. C., Schouten, S., Bohaty, S., Quattlebaum, T., Sluijs, A., Brinkhuis, H., Gibbs, S. J., and Bralower, T. J.: Extreme warming of mid-latitude coastal ocean during the Paleocene-Eocene Thermal Maximum: Inferences from $\mathrm{TEX}_{86}$ and isotope data, Geology, 34, 737-740, 2006. 